ANNA SÁDOVSKÁ

Faculty of Education

Trnava University in Trnava

Slovakia

ORCID ID: http://orcid.org/oooo-ooo3-3309-4819
Forum Pedagogiczne

9 (2019) 2, cz. 2

Wpłynęło: 13.10.2019

Zatwierdzono do druku: 20.11.2019

DOI: 10.21697/fp.2019.2.39

\title{
WHAT DO YOUTH REALLY CARE FOR? TOWARDS ETHICAL EDUCATION, EDUCATION FOR SUSTAINABLE DEVELOPMENT AND YOUTH VALUES
}

\begin{abstract}
Article contains some thoughts and ideas on how education for sustainable development can be included in school education and how it interconnects with Ethical Education that could become a school subject that promotes education for sustainable development. Results of research focused on pupils' values oriented on environmental care and their correlation with self-perceived prosocial behaviour and the so-called social pessimism are presented. These results show a significant correlation between hedonism and universalism, between self-perceived prosocial behaviour and universalism. It was found that a lower scale of social pessimism correlates with a higher scale of values of universalism.
\end{abstract}

Keywords: Ethical Education; sustainable development; youth; values.

\section{Introduction}

Recent events that raised voices of youth population and warnings issued by environmental scientists should make us aware that part of human population does not behave in the way that promotes sustainability of our planet and human beings.

Education for Sustainable Development (ESD) is defined by UNESCO (Leicht, Heiss, Byun, 2018, p. 32) as education that allows "every human being to acquire the knowledge, skills, attitudes and values necessary to shape a sustainable future. Education for Sustainable Development means including key sustainable development issues into teaching and learning; for example, climate change, disaster risk reduction, biodiversity, poverty reduction, and sustainable consumption." On the other hand, European Commission divided the agenda of sustainable development into seventeen sustainable development goals including new topics, e.g. quality education, gender equality, and topics aimed at environment, healthy 
living and bio-diverse sustainability (no poverty, no hunger, safe water, sustainable cities and communities, climate actions etc.).

These goals correspond with a classical triad of the sustainability - its social, economic and environmental dimensions. Social sustainability refers "to the social goals of sustainability strategies" (Patridge, 2014, p. 6178) and it occurs when the formal and informal processes, systems, structures and relationships actively support the capacity of current and future generations to create healthy and liveable communities." (McKenzie, 2004, p. 35) Economic sustainability is focused on using, safeguarding and sustaining all resources to create long-term sustainable values by the optimal use, recovery and recycling.

In my article, I decided to focus only on the environmental dimension of sustainability concept. I would like to consider and review ideas of how to introduce ESD to school education. My primary focus includes these topics and parts of EDS which are connected with environment, biodiversity and climate change, and eco-friendly behaviour of pupils.

Firstly, I will discuss an interconnection of ESD and Ethical Education that could become a school subject, in which ESD is developed. I will discuss various reasons we should consider sustainable behaviour. Secondly, I will present results of research focused on pupils' values oriented on environmental care and their correlation with self-perceived prosocial behaviour and so-called social pessimism.

\section{Interconnections of Education for Sustainable Development and Ethical Education}

Readiness of pupils (and adults) for sustainable behaviour is a result of appropriate knowledge, skills, attitudes and values. The role of education is not only to be a source of knowledge and skills, It also fosters formation of attitudes and values that are building blocks for sustainable behaviour of every individual.

In my text, I would like to emphasise that our decisions that are loosely related to our daily life are based on our beliefs, attitudes and values. In other words, what I believe in is right. One of the ways to facilitate and form pupils' value orientation and their willingness to live their lives as virtuous persons is Ethical Education (see Table 1 and selected topics developed in Ethical Education in Slovakia).

During a discussion with pupils on environmental care as the value and virtue, it was noticed that their line of reasoning copies some well-known concepts and arguments. From social-psychological point of view, values are "internalized cognitive structures that guide choices by evoking a sense of basic principles of right and wrong, a sense of priorities, and create a willingness to make meaning and see patterns." (Oyeserman, 2015, p. 36) Values form the individual beliefs and attitudes towards which certain activity/thing/performance are right and worthwhile. In addition, values are perceived as a social phenomenon; they are created as a certain agreement in society and they are transmitted in that meaning. Values function as 
Table 1. ESD in the ethical education curriculum (ISCED2, ISCED3) in Slovakia

\begin{tabular}{|l|l|l|}
\hline Topic & Content & Values/virtues \\
\hline $\begin{array}{l}\text { Complex } \\
\text { Prosociality }\end{array}$ & $\begin{array}{l}\text { evidence and consequences of } \\
\text { social inequality, reasoning of } \\
\text { solidary behaviour, } \\
\text { need for help of vulnerable } \\
\text { groups }\end{array}$ & $\begin{array}{l}\text { solidarity } \\
\text { helping people in worse } \\
\text { living conditions } \\
\text { equality }\end{array}$ \\
\hline $\begin{array}{l}\text { Economic } \\
\text { Values and } \\
\text { Ethics }\end{array}$ & $\begin{array}{l}\text { pros and cons of ownership, } \\
\text { relationship to possession/mo- } \\
\text { ney (instrumental or terminal } \\
\text { value) } \\
\text { consumer behaviour } \\
\text { human work }\end{array}$ & $\begin{array}{l}\text { moderation in ownership } \\
\text { fair/straight work } \\
\text { to deny buying unnecessary } \\
\text { things } \\
\text { to use the resource to develop } \\
\text { welfare }\end{array}$ \\
\hline $\begin{array}{l}\text { Ethical } \\
\text { Aspects of } \\
\text { Environmental } \\
\text { Care }\end{array}$ & $\begin{array}{l}\text { personal responsibility for } \\
\text { environment, } \\
\text { considering the relationship to } \\
\text { nature, } \\
\text { project on nature preservation } \\
\text { in local community and own } \\
\text { pupils environmental activities }\end{array}$ & $\begin{array}{l}\text { responsibility } \\
\text { proactivity } \\
\text { care for all parts of biosphere } \\
\text { reasonable use of resource }\end{array}$ \\
\hline
\end{tabular}

Source: authors' own elaboration.

an organized system and are typically viewed as determinants of attitudes and behaviours (Olson, Zanna, 1994).

Nowadays, a stream called the environmental psychology is developed in theory of psychology. Within it, various concepts are proposed, e.g. Stern and Dietz's (1994) value-based theory of environmental concern. According to them, environmental attitudes (egoistic, social-altruistic, biocentric) are the result of person's more general set of values. These are similar to well-known egocentric, anthropocentric and biocentric dimensions by Merchant (1992).

Kempton et al. (in Stern, Dietz, 1994) mentioned egoistic environmental attitudes based on beliefs about the effect that environmental destruction may have on the individual (e.g. the environment should be protected because I do want to breathe fresh air). Secondly, social-altruistic environmental attitudes are based on human benefits or human goals (e.g. I protect the environment because it causes long-term consequences on other people). Finally, biocentric attitudes focus on the inherent value of the natural environment (all species have a right to continue their existence).

In a wider interdisciplinary concept of values, the specific group of environmental values was developed. There is supposed to be an important factor influencing decision-making. Dietz (2016, p. 331-336) summarizes some values, which are believed to be the most important influences upon our environmental decision-making: 
- self-interest - an individual uses the resource at the level that is most beneficial to him/her regardless of the consequences (risk of the resource degradation);

- altruism towards other humans/biospheric altruism - an individual acts "with some degree of altruism directed toward other resource users or toward other species or the biosphere itself" and it supports the sustainability of resources;

- openness to change (according to Schwartz's theory, e.g. 1994, 2010) could have a relation to a willingness to adopt pro-environmental behaviours as soon as possible;

- hedonic values (importance to pleasure and comfort) in negative way - proenvironmental behaviour causes the lack of comfort, which individuals do not want to experience (on the other hand, individual pleasure can be connected with the need to live in healthy environment and can be motivation for action; author's remark).

\section{Tasks of Ethical Education and Education for Sustainable Development}

Our daily lives, as well as the daily lives of our students, are set in a relatively close environment and parts of the world reality are hidden from our personal experience. For sure, comparing past periods, we are able to obtain more information (and very current events) in the actual time, but at the same time, we are more replete with information and resistant to actions. Recent development of society (in Europe, see e.g. results of DEREX Index, 2019) shows some features of pessimism which can support the reasoning why not to try to change anything ("I am only one"; "the organizations and companies should change their behaviour and approach to environmental issues"; "everyone is responsible for his/her life", "it is not my deal"). All efforts in sustainable development have a form of synergic cooperation of individuals and organizations as proposed e.g. by Stern (2000) "focus on individual behaviour can cause underestimating of roots and consequences of environmental problem." In that way, the value structure formation of pupils can be realized during the lessons of Ethical Education.

Finally, one of the key tasks of the Ethical Education is to make students aware of horizontal and vertical line of human behaviour and its results. It is clear that reasons for sustainability-friendly behaviour can follow various personal/individual concepts and ways of interiorizing certain values. This could be Kant's categorical imperative transformed by Jonas (2004, p. 109): "Act so that the effects of your action are consistent with a continuing genuine life on earth." In other words, we should try to apply a universal moral rule in the horizontal and vertical line to act considering needs and freedom of people in this time, but also in the future (needs of the next generations). Application of universal moral rules in the vertical line means that my behaviour has a direct impact on other people in present days. 
Horizontal line is meant as necessity to reflect the consequences of my recent behaviour on people who are going to be born and live in the same environment.

In the sense of hedonic values, we are seemed to be looking for comfort and pleasure. As was mentioned above, this can be a reason why not to behave in a sustainable-friendly manner. Our comfort is very often preconditioned for finding some excuses that "switch-off" our conscience and justify our behaviour as right. It can be present in any tiny daily situation.

Psychological concepts describing moral development (e.g. Piaget, Kohlberg) or moral reasoning (e.g. Eisenberg) work with the human being included in the society. The society, role models and social beliefs, norms, attitudes and values are prerequisites for adopting and repeating certain kind of moral behaviour. In the case of the right environmental behaviour, we are not subjected to many commands and imperatives.

Teachers should be ready for discussing many various ways of pupils' reasoning why to present sustainable-friendly behaviour or not. Pro-environmental behaviour, as was mentioned, arises in specific conditions and circumstances. Those can support our decisions to act or not to act in favour of environment, as well as next generations.

As an example, I will use very simple model of behaviour: "The case of a plastic cup." The responsible behaviour could be defined as: "If there is no other way, I will use a plastic cup. However, I will try to find a correct recycling bin and throw the used plastic cup in it." In this case, people's behaviour could be supported by many reasons and, at the same time, there are many reasons why do not act in this way (and reasons which excuse us or disengage us from the responsibility).

Inspired by Eisenberg's classification (1983) of prosocial moral reasoning the possible decisions to act could be following:

- I will throw the plastic cup in the assigned recycling bin, because I want to live in the environment without pollution. (For sure, the result of act is useful for planet, but the reason could be discussed. Is it enough to think only of my needs?)

- I will do it, because I want other people to see me that I act in this way. (This reason could work when my performance has some observers and I want to build my positive image. If there are no observers, will I or will I not act eco-friendly?)

- I will do it, because this behaviour is approved within the society. Maybe, it is not important what I really think about, the most important is my satisfaction when somebody approves my behaviour.

- I will do it, because I feel for next generations, that they will not experience the planet with beautiful nature and breathable air. This performance is connected with the feeling of guilt or satisfaction related to consequences of performing. 
- I will do it, because it is one of the rules of my proper behaviour. I feel that it is my duty/responsibility not to break this rule.

- - I will do it, because it is a principle in my life (as an awareness of necessity not to litter the planet with more rubbish and try to re-use it, not only for me but also for others). In this case, the internalized behaviour is connected to higher quality and frequency of prosocial behaviour.

Now, I think, it is important to answer the question: Why is it necessary to work with reasoning and with value reflection of pupils' performance? Teachers of Ethical Education (and other teachers) should be able to recognize level of pupils' reasoning to support their improvement in reaching higher levels of internalized actions. No doubt, that all mentioned reasons bring positive consequences. However, only higher-internalized kind of behaviour can sustain and be repeated more frequently. Many ways of our pro-environmental actions are not enforced by law, they are not part of strict and strong moral rules and because of that, they do not deserve our attention (in some social and cultural conditions).

\section{Environmental care and youth}

For teachers who want to develop and improve sustainability-friendly and pro-environmental reasoning is quite necessary to understand which value can support another value. As was mentioned above, the willingness to perform pro-environmental behaviour could rise from openness to change.

Research on environmental care or values in connection to youth population is greatly varied. Scientists are interested in e.g. environmental responsibility and its relation to environmental values (Slavoljub et al., 2014); environmental attitudes and their trends in the process of time (Wray-Lake et al., 2010) or reasons the youth participates in environmental policy (Paloniemi, Vainio, 2011).

According to Wray-Lake et al. (2010) tendencies show strong associations between personal responsibility, conservation behaviours and belief in resource scarcity. It is stated that awareness of resource scarcity and lower materialist aspirations support the youth to be more willing to take actions in conserving these resources. In addition, it was found that anthropocentric values develop the personal environmental responsibility more strongly than biocentric values and values are "strong predictors of environmental responsibility among young people and have a direct impact on its development." (Slavoljub et al., 2014) Paloniemi and Vainio (2011) noted that post-materialist values and political competence are the most important elements behind the interest in environmental political actions. The decision for environmental actions is connected with trust in the political system, its institutions and outcomes. 


\section{Research aims and questions}

According to mentioned researched results, I decided to follow some specific relations between inclination to environmental care, inclination to hedonic life-style, self-perceived prosocial behaviour and social pessimism attitudes.

As was mentioned, our care for the environment can be motivated by our egoistic need to live in healthy environment. This was the background for the first research question.

Research question 1: Does pupils' positive perception of value of universalism correlate to their positive perception of hedonic values?

Some people are motivated by their conviction that the Earth and its nature should be preserved for the next generations and this action bears the stamp of prosocial behaviour. Following this, it is interesting to carry out the relation between prosocial behaviour and positive attitude towards environmental care.

Research question 2: Does pupils' positive perception of value of universalism correlate to their self-perceived prosocial behaviour?

My interest is focused on connections between the trust in social and political institutions; the belief that me as a citizen can change something in the society or not (it means social pessimism) and the conviction of necessity of environmental preservation.

Research question 3: Does pupils' positive perception of value of universalism correlate to their social pessimism attitudes?

\section{Research sample/participants}

Participants were involved in research by simple intentional sampling. The primary criterion was their age, respectively their attendance of the $2^{\text {nd }}$ and $3^{\text {rd }}$ grade of higher secondary school. Data collection was anonymous and was realized in two one-off sessions with participants in February and March in 2019. The participants were asked to fill out digital questionnaires. This procedure guaranteed a $100 \%$ completion of research instruments.

The sample of pupils consisted of 226 Slovak secondary school pupils (109 males, 117 females) attending nine different schools in western regions of Slovakia. The schools were chosen randomly, but it was important to create the research sample containing proportional number of students from general higher secondary schools $(n=102)$ and vocational schools $(n=124)$. The majority of participants were 18 years old $(46 \%, n=105), 31 \%$ of pupils were 17 years old $(n=70), 19 \%$ were 16 years old $(n=43), 4 \%$ of them were 19 years old $(n=8)$. 
Participation in the research was voluntary and none of the pupils was paid for their participation. Parental consent was obtained, and all data stored according to data protection regulations.

\section{Methods}

For the measurement of pupils' value orientation, the Portrait Value Questionnaire (PVQ) by Schwartz $(1994,2003)$ was used. It contains items in form of statements and respondents need to choose the proper scale of agreement. This version was refined some years later by Schwartz (2012), but only a ten-value questionnaire was distributed since it is comparable with some important results with previous research and results. The statements link to the ten values constructed mainly by Schwartz (2006, p. 267), who presents also definitions of motivational types of values in terms of their goals (power, achievement, hedonism, stimulation, self-direction, universalism, benevolence, tradition, conformity, security). The environmental care is represented in the statement: "S/He strongly believes that people should care for nature. Looking after the environment is important to her/him, which is the part of value universalism." ${ }^{22}$

To have information about self-perceived prosocial behaviour of pupils, the Questionnaire of Prosocial Behaviour (PROS by Roche, Sol 1998) was used. It was revised and adapted in some previous research (Rajský, Podmanický 2016). The content of PROS is based on items representing some types of prosocial behaviour (e.g. "I like helping others"; "I often encourage others" or "I willingly share with others.") and pupils had to express how much they agree or disagree with these statements.

Social pessimism is very often researched in connection to negative social phenomena (radicalism, extremism). In this study, to follow social pessimism within the research sample, I used an instrument of Violent Extremism Disposition Scale by Davydov and Khlomov (2017). This instrument also contains more subparts. In this study, I focused only on the part called social pessimism. Examples of items on social pessimism: "In our society there is no point in being honest and taking care of the environment, while others continue to deceive and spoil everything around us"; "Our society is on the brink of doom."

22 According to Schwartz (2006): Universalism (broadminded, wisdom, social justice, equality, a world at peace, a world of beauty, unity with nature, protecting the environment): Understanding, appreciation, tolerance and protection for the welfare of all people and for nature. 
Results, interpretation and discussion

\section{Universalism and Hedonism}

The scores of males and females in the research sample were without significant differences and I collected the results for the sample as a whole. The mean score of universalism $(\mathrm{M}=4.18, \mathrm{SD}=1.08)$ is moderately higher than the mean score of hedonism $(\mathrm{M}=3.77, \mathrm{SD}=0.99)$.

Correlation of hedonism and universalism values shows that higher score of universalism correlates significantly with higher score of hedonism (Table 2). It supports the above-mentioned assumption that pupils' pro-environmental care can be motivated by an individual need - living in healthy environment as a way to enjoy and live life to the fullest.

Table 2. Correlation analysis

\begin{tabular}{|l|c|l|c|}
\hline \multirow{2}{*}{} & \multicolumn{3}{|c|}{ Universalisms } \\
\cline { 2 - 4 } & $\mathrm{r}$ & \multicolumn{1}{|c|}{$\mathrm{r} 2$} & $\mathrm{p}$ \\
\hline Hedonism &, 46 & 0.10 &, $\mathrm{o0^{** }}$ \\
\hline $\begin{array}{l}\text { Self-perceived prosocial } \\
\text { behaviour }\end{array}$ &, 31 & 0.26 &, $\mathrm{Oo}^{* *}$ \\
\hline Social pessimism attitudes &, 35 & 0.04 &, $\mathrm{Oo}^{* *}$ \\
\hline
\end{tabular}

$\mathrm{n}=\mathbf{2 2 6}$; $\mathrm{r}$ - Pearsons correlation coeffiecient; $\mathrm{r} 2$-effect size coefficient of determination; $\mathrm{p}$ - significance value.

\section{Universalism and self-perceived prosocial behaviour}

The results in Table 1 shows that pupils' positive perception of value of universalism significantly correlates to their self-perceived prosocial behaviour.

Prosocial behaviour is usually connected with the value of benevolence, since benevolence values emphasize voluntary concern for others' welfare and promote cooperative and supportive social relations (Schwartz, 2012).

It can be supposed that a strong correlation between universalism and selfperceived prosocial behaviour is connected to concerns for the welfare of people in larger society and the world and for nature, because those concerns can be a motivation for pupils' prosocial behaviour. Schwartz (2012) argues that universalism values derive from survival needs of individual and groups. People may realize that failure to protect the natural environment will lead to the destruction of the resources on which life depends. In this way, the universalism values are part of a complex prosocial behaviour, which supports wider society, institutions and groups of people. 


\section{Universalism and social pessimism attitudes}

To describe the score of social pessimism attitudes, I should mention that the results according to sex were without significant differences. The mean scores of the whole group was slightly higher than middle value $(M=3.18)$, which shows the unsure refusal of impossibility to change the state of society, institution, etc. The most pessimistic is an opinion on future developments - pupils expect a crisis, political conflicts and wars because of existing insecurity and instability.

The correlation of value scores and a score in social pessimism attitudes shows the significant correlation between universalism and social pessimism attitudes. Higher conviction about the value of universalism correlates with refusal of social pessimism attitudes.

\section{Conclusion}

This article discusses an issue of Education for Sustainable Development as a part of the school subject called Ethical Education. Many ethical questions are connected with topics which are nowadays the content of wider concept of ESD (e.g. solidarity, helping people in worse living conditions, equality, care for all parts of biosphere, reasonable use of resource).

Environmental issues and pro-environmental care are in the centre of attention, since recent circumstances and the youth's interest in pro-environmental care call for teachers' readiness to discuss theoretical basis of the problem but also to consider reasons for pupils' pro-environmental actions.

Teacher-pupils' discussions about egoistic, social-altruistic and biocentric environmental attitudes and values important for pupils' decision-making (selfinterest, human altruism, openness to change, hedonic values) should lead to their careful re-thinking and re-constructing of individual value orientation. One of the key tasks of the Ethical Education is to make pupils aware of horizontal and vertical lines of human behaviour and its results. The vertical line of prosocial human behaviour is present in conviction that my recent responsible pro-environmental behaviour brings next generations possibilities to live in similar living conditions, to experience the planet and its nature as I am experiencing it today.

The close connection between Ethical Education and ESD is present in an idea that ESD has to consider a basic moral framework and develop some related skills and abilities: moral judgement, moral knowledge, competence of moral reflection and moral courage (Schank, Rieckmann, 2019). The curriculum of Ethical Education in Slovakia, but also curricula of comparable school subjects focused on moral/ ethical education in many countries, contain topics, which can develop mentioned skills and abilities. The second advantage of Ethical Education is that lessons (and therefore topics aimed at pro-environmental care) are realized via experiential learning. Recent studies show that experiential learning and personal encounters with environmental issues in specific conditions (summer camps, long-term or 
short-term programmes) can change pupils' habits and consumption behaviour or influence their attitude towards nature. To be more specific, I can mention some examples: Intervention in the Sustainable Living and Learning Community (SLLC) Programme, which developed understanding of term sustainability and 75 per cent students modified their habits and behaviour (Lewis et al., 2019). Environmental education programmes can increase students' understanding of ecological issues, their perceptions of the presence and importance of nature in the local urban setting (Kudryavtsev et al., 2012). These results support an assumption that well-organized and taught lessons on ESD within Ethical Education can influence pupils' proenvironmental attitudes and eco-friendly behaviour.

Finally, I presented brief correlations between pupils' universalism value and hedonic value, self-perceived prosocial behaviour, social pessimism and trust in institution. It was shown that pupils' hedonism values correlate positively with their universalism values. The desire for living in healthy environment can support their willingness to behave environmentally friendly. Similarly, pupils' self-perceived prosocial behaviour significantly correlates with universalism values. Universalism values are connected with complex pro-sociality and willingness to benefit people whom we do not know personally (solidary actions in present, but also pro-environmental actions in favour of unknown next generations). Social pessimism is in contraposition to pupils' universalism values. It means, that a higher scale of social pessimism correlates with a lower scale of pupils' conviction about necessity to support human welfare and nature of the Earth.

\section{Acknowledgments}

This work was supported by Ministry of Education, Science and Sport of Slovak Republic, via project VEGA 1/0056/19 Moral Reflection as a Primary Component of Character Education under Conditions of Implementation of the School Subject Ethical Education.

\section{References}

Brennan A., Lo, Y. (2016). Environmental Ethics. In: E. N. Zalta (Ed.). The Stanford Encyclopedia of Philosophy, available at: https://plato.stanford.edu/archives/ win2016/entries/ethics-environmental (Retrieved 25.04.2019).

Davydov, D., Khlomov, K. (2017). Questionnaire for the Diagnosis of Violent Extremism Attitudes. SSRN Electronic Journal, available at: https://www.researchgate.net/publication/321380130_Questionnaire_for_the_Diagnosis_of_ Violent_Extremism_Attitudes (Retrieved: 12.12.2018).

Derex Index. Demands on Right-Wing Extremism. (2019). Available at: http://derexindex.eu/ (Retrieved 05.01.2019). 
Dietz, T. (2016). Environmental Value. In: T. Brosch, D. Sander (Eds.). Handbook of Value. 2016. Perspectives from Economics, Neuroscience, Philosophy, Psychology and Sociology (pp. 329-350). Oxford University Press.

Eisenberg, N., Lennon, R., Roth, K. (1983). Prosocial Development: A Longitudinal Study. Developmental Psychology, 19, pp. 846-855.

Jonas, H. (2004). Leben, Wissenschaft, Verantwortung. Stuttgart: Reclam.

Kudryavtsev, A., Krasny, M. E., Stedman, R.C. (2012). The impact of environmental education on sense of place among urban youth. Ecosphere, 3 (4). http://dx.doi. org/10.189o/ES11-00318.1

Leicht, A., Heiss, J., Byun, W. J. (Eds.) (2018). Issues and Trends in Education for Sustainable Development. Paris: UNESCO Publishing. Available at: https:// unesdoc.unesco.org/ark:/48223/pfoooo261445 (Retrieved: 06.02.2019).

Lewis, R. A., Kenerson, M. J., Sorrentino, C., Rowse, T. H. (2019). Experiencing Sustainability Education: Insights from a Living and Learning Programme. Journal of Education for Sustainable Development, 13 (1), 24-44. doi:10.1177/0973408219847011.

McKenzie, S. (2004). Social Sustainability. Towards some definitions. Working Paper. Hawke Research Institute, University of South Australia. Available at: aturalcapital. us/images/Social Sustainability - Towards Some Definitions_20100120_024059. pdf (Retrieved: 10.10.2019)

Merchant, C. (1992). Radical Ecology: The Search for a Livable World. New York: Routledge.

Olson J., Zanna M. (1993). Attitudes and attitude change. Annual Review of Psychology, 44, 117-154.

Oyeserman D. (2015). Values, Psychology of. In: J. D. Wright (Ed.). International Encyclopedia of the Social and Behavioural Sciences, Vol 25, (pp. 36-40).Oxford: Elsevier.

Paloniemi, R., Vainio, A. (2011) Why Do Young People Participate in Environmental Political Action? Environmental Values, 20, 397-416. doi: 10.3197/o96327111X13 077055166108

Partridge, E. (2014). Social Sustainability. Encyclopedia of Quality of Life and WellBeing Research, pp. 6178-6186. doi:10.1007/978-94-007-0753-5_2790

Rajský, A., Podmanický, I. (Eds.) (2016). Človek človeku. K prameňom etickej výchovy. Trnava: VEDA.

Roche, R. O., Sol, N. (1998). Educación prosocial de las Emociones, Valores y Actitudes positivas. Barcelona: Blume.

Schank, C., Rieckmann, M. (2019). Socio-economically Substantiated Education for Sustainable Development: Development of Competencies and Value Orientations Between Individual Responsibility and Structural Transformation. Journal of Education for Sustainable Development, 13(1), 67-91. doi:10.1177/0973408219844849 
Schwartz, S. H. (1994). Are there universal aspects in the structure and contents of human values? Journal of Social Issues, 5o(4), pp. 19-45.

Schwartz, S. H. (2010). Basic values: How they motivate and inhibit prosocial behavior. In M. Mikulincer, P. R. Shaver (Eds.). Prosocial motives, emotions, and behavior: The better angels of our nature (pp. 221-241). Washington, DC: American Psychological Association.

Schwartz, S. H. (2012). An Overview of the Schwartz Theory of Basic Values. Online Readings in Psychology and Culture, 2(1). doi.org/10.9707/2307-0919.1116.

Slavoljub, J. et al. (2014). To the environmental responsibility among students through developing their environmental values. Procedia - Social and Behavioural Sciences, pp. 317-322.

Stern P.C. (2000). Psychology and the science of human-environment interactions. American Psychologist, 55(5), 523-530.

Stern, P. C., Dietz, T. (1994). The Value Basis of Environmental Concern. A Journal of the Society for the Psychological Study of Social Issues, 65-84.

European Commission. (2019). The Sustainable Development Goals. Available at: https://ec.europa.eu/sustainable-development/goal4_en (Retrieved 25.04.2019). Wray-Lake, L., Flanagan, C. A., Osgood, D. W. (2010). Examining Trends in Adolescent Environmental Attitudes, Beliefs, and Behaviors Across Three Decades. Environmental Behaviour, 42(1), 61-85. doi:10.1177/0013916509335163.

\section{NA CZYM TAK NAPRAWDE ZALEŻY MLODZIEŻY? DZIAŁANIA NA RZECZ KSZTAŁCENIA ETYCZNEGO, EDUKACJI DLA ZRÓWNOWAŻONEGO ROZWOJU I WARTOŚCI U MŁODZIEŻY}

Streszczenie: Artykuł dotyczy pytania: w jaki sposób można włączyć edukację na rzecz zrównoważonego rozwoju w nauczanie i uczenie się szkolne i powiązać z wychowaniem moralnym i kształceniem etycznym? Autorka przedstawia wyniki badania dotyczącego wartości i postaw proekologicznych uczniów, które przeanalizowała w powiązaniu z deklarowanymi przez nich zachowaniami prospołecznymi i tak zwanym pesymizmem społecznym. Dzięki analizie stwierdziła zachodzenie znaczącej korelacji między postawą hedonistyczną a uniwersalistyczną oraz między deklarowanymi zachowaniami prospołecznymi a uniwersalizmem światopoglądowym. Ponadto okazało się, że niższy poziom skali pesymizmu społecznego koreluje z wyższym poziomem skali uniwersalizmu.

Słowa kluczowe: kształcenie etyczne; zrównoważony rozwój; młodzież; wartości.

Anna Sádovská - $\mathrm{PhD}$, her interests are focused on methodology of Ethical Education, Moral Education, educational counselling and multicultural education in her research 
and educational activities. She also researches prosocial behaviour and moral reasoning of pupils, field of perception of cultural diversity by pupils and inclusion of pupils in mainstream schools. As a member of Central Committee for Ethical Education she has taken part in improving of educational content of Ethical Education. E-mail-Address: anna.sadovska@gmail.com. 